\title{
Useful access to enantiomerically pure protected inositols from carbohydrates: the aldohexos-5-uloses route
}

\author{
Felicia D'Andrea ${ }^{1}$, Giorgio Catelani ${ }^{1}$, Lorenzo Guazzelli ${ }^{* 1}$ and Venerando Pistarà ${ }^{2}$
}

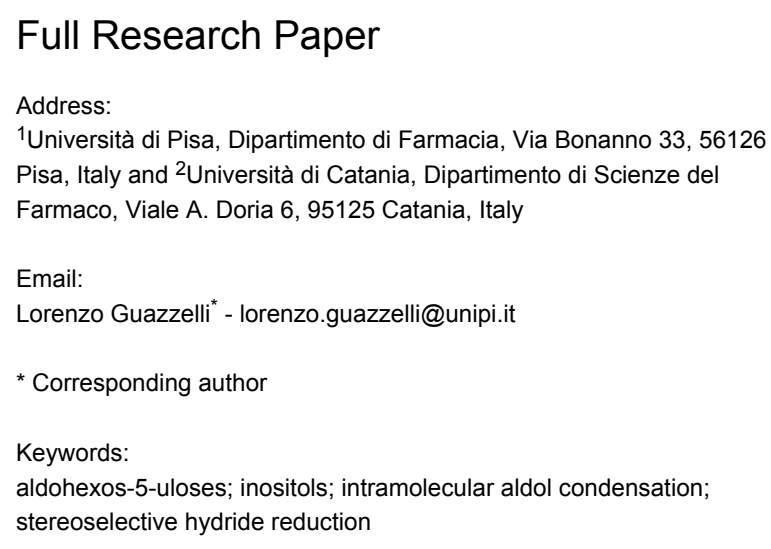

Beilstein J. Org. Chem. 2016, 12, 2343-2350.

doi:10.3762/bjoc. 12.227

Received: 02 August 2016

Accepted: 19 October 2016

Published: 08 November 2016

Associate Editor: S. Flitsch

C 2016 D'Andrea et al.; licensee Beilstein-Institut.

License and terms: see end of document.

\begin{abstract}
The intramolecular aldol condensation of aldohexos-5-ulose derivatives of the D-xylo and L-ribo stereoseries has been studied. Only one of the four possible inososes was isolated from both stereoseries in reasonable yields (30-38\%). The results obtained, together with the previous findings for the L-arabino and L-lyxo stereoseries, allowed for the rationalisation of a mechanism of the reaction based on open-transition-state models and electron-withdrawing inductive effects. Complementary reductions of the intermediate inososes were possible by changing the reaction conditions, and two isomeric inositol derivatives were obtained with complete stereoselection from each inosose. The presented approach permits us to control the configuration of three out of the six stereocentres of the inositol frame and gives access to seven of the nine inositols. Noteworthy, for the D-xylo derivative, the twostep sequence (condensation followed by reduction with $\mathrm{NaBH}(\mathrm{OAc})_{3}$ ) represents the biomimetic synthesis of myo-inositol. Furthermore, the sugar-based pathway leads directly to enantiomerically pure selectively protected inositols and does not require any desymmetrisation procedure which is needed when myo-inositol and other achiral precursors are employed as starting materials. As an example of application of the method, the indirect selective protection of secondary inositols' hydroxy functions, by placing specific protecting groups on the aldohexos-5-ulose precursor has been presented.
\end{abstract}

\section{Introduction}

Inositols are a family of biologically relevant compounds $[1,2]$ constituted by nine stereoisomeric hexahydroxycyclohexanes (Figure 1): five have been found in nature (myo, scyllo, D-chiro, $L$-chiro, and neo), while the remaining four are unnatural synthetic products (cis, epi, allo, and muco).
Several myo-inositol phosphates, for instance D-myo-inositol1,4,5-triphosphate $\left[\mathrm{D}-\mathrm{I}(1,4,5) \mathrm{P}_{3}\right]$ and D-myo-inositol-1,3,4,5tetrakisphosphate $\left[\mathrm{D}-\mathrm{I}(1,3,4,5) \mathrm{P}_{4}\right]$, are ubiquitous in all living organisms. They are involved in different crucial cellular functions which spread from cell growth to intracellular 


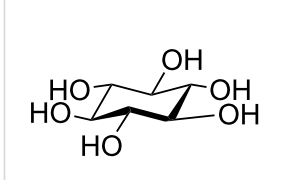

scyllo-inositol

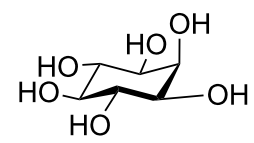

myo-inositol

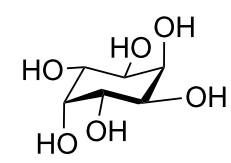

neo-inositol<smiles>OC1C(O)C(O)C(O)C(O)C1O</smiles>

epi-inositol

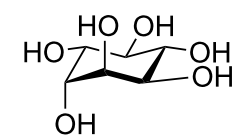

D-chiro-inositol

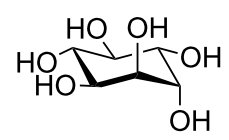

L-chiro-inositol

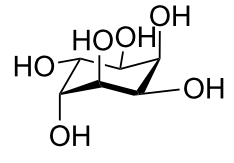

allo-inositol<smiles>OC1C(O)C(O)C(O)(O)C(O)C1O</smiles>

cis-inositol

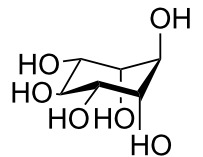

muco-inositol

Figure 1: Stereoisomeric inositols.

signal transductions events [3-5]. The field investigating inositol phosphates and their involvement in mediating certain aspects of cell biology is continuously broadening. Hence, a deeper understanding of how they act on a molecular level is required.

For this reason, many research efforts were directed toward the investigation of the structure-activity relationship (SAR) between inositol phosphates and biomacromolecules. These studies require various regio- and stereoisomers of inositol phosphates $[6,7]$ and have prompted the development of practical and efficient synthetic methods for stereoselectively accessing all natural and unnatural inositols as well as their derivatives.

There are three general synthetic approaches to prepare inositols: 1) stereoselective elaborations of the inexpensive, commercially available myo-inositol [8-13]; 2) elaboration of the six carbon atom skeleton of either a) tetrahydroxycyclohexene derivatives $[14,15]$ (synthetic or natural conduritols) through stereoselective cis-hydroxylation or epoxidation-hydrolysis of the double bond or b) benzene [16,17] or halo-benzenes [1821 ], by microbial oxidation; 3) carbocyclization involving organometallic intermediates (Ferrier II reaction [22] performed on 6-O-acyl-hex-5-enopyranosides followed by reduction $[23,24]$; trialkylaluminium $[25,26]$ or titanium(IV)-assisted
[27] conversion of hex-5-enopyranosides and $\mathrm{SmI}_{2}$-promoted [28-30] pinacol coupling of dialdehyde derivatives).

A strategy related to the latter approach relies on a basepromoted aldol condensation of aldohexos-5-uloses followed by reduction of the carbonyl group, as reported in the retrosynthetic Scheme 1. This method again uses sugars as starting material but differs from previous work in that it is metal-free.

The first application of this approach was described by Kiely [31,32] who obtained a sample of myo-inositol in a mixture with other non characterised stereoisomers by treating D-xylohexos-5-ulose [31] and its 6-phosphate [32] with $0.1 \mathrm{~N}$ aqueous $\mathrm{NaOH}$ followed by $\mathrm{NaBH}_{4}$ reduction of the crude inosose mixture.

Although these pioneering results were not of synthetic significance, they elucidated for the first time the biosynthetic correlation between D-glucose and myo-inositol through the intermediate formation of D-xylo-hexos-5-ulose. A more synthetically useful result was obtained when the aldol condensation of aldohexos-5-uloses derivatives was run in organic solvents in the presence of an organic base. The reaction occurred in a completely stereocontrolled manner and led to a single inosose intermediate [33-35]. The subsequent stereoselective reduction gave single inositols in good yields: epi-inositol starting from

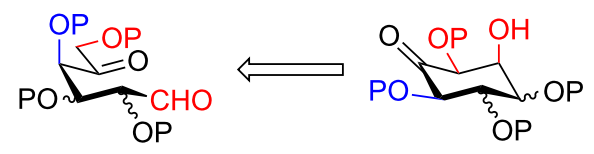

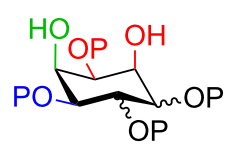

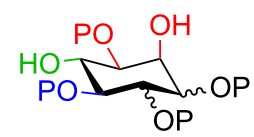


L-arabino-hexos-5-ulose [33] and D-chiro-inositol starting from the L-lyxo stereoisomeric dicarbonyl precursor [34].

Taking these considerations into account, we have recently completed the preparation of at least one enantioform of the four diastereoisomeric aldohexos-5-ulose series. A general approach was developed starting from $\beta$-D-galactopyranosides, including the commercially and cheaply available lactose [36-38].

Presented here is the extension of the above synthetic route to inositols using aldohexos-5-uloses derivatives of the D-xylo and L-ribo series, respectively $\mathrm{C}-4$ and C-2 epimers of the L-arabino series. Based on these aldol condensations together with the work previously performed on the L-arabino [33] and
L-lyxo [34] series, a working mechanism is presented to explain the complete stereocontrol over the formation of the two new stereogenic centres (red in Scheme 1). Furthermore, the stereochemical outcome of the intermediate inososes reduction by using different reagents, namely the stereocontrol over a third stereogenic centre (green in Scheme 1), is also reported.

\section{Results and Discussion}

The aldol condensation reactions were performed at room temperature by treating aldohexos-5-ulose derivatives with catalytic amounts of $\mathrm{DBU}$ ( 0.15 equiv) as an organic base promoting agent in toluene, a 1:1 mixture of toluene- $\mathrm{CH}_{2} \mathrm{Cl}_{2}$, or $\mathrm{CH}_{2} \mathrm{Cl}_{2}$ to circumvent solubility problems (Table 1, see Supporting Information File 1 for full experimental data).

Table 1: Preparation of inosose derivatives $5-8$ and 11-12 by intramolecular aldol condensation of aldohexos-5-uloses derivatives 1-4 and 9-10.

Compound

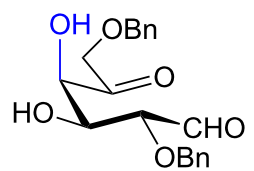

1 (L-arabino)<smiles>O=C[C@@H]1C(O)=C(COCBr)C(O)C(O)C1(Br)Br</smiles>

2 (L-ribo)

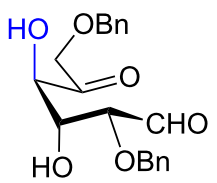

3 (L-lyxo)

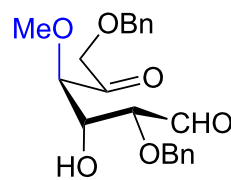

4 (L-lyxo)<smiles>O=C[C@H](OBr)[C@H](O)[C@H](O)C(=O)CO[Sn]</smiles>

9 (D-xylo)<smiles>[B]OC(C(C=O)OBr)C(O)C(=O)COc1ccccc1</smiles>

10 (D-xylo)
$5 \%$ DBU solution, dry toluene, $\mathrm{rt}, 6 \mathrm{~h}$

$5 \%$ DBU solution, dry $\mathrm{CH}_{2} \mathrm{Cl}_{2}, 0{ }^{\circ} \mathrm{C}, 1.5 \mathrm{~h}$

$5 \%$ DBU solution, dry $1: 1$ toluene $/ \mathrm{CH}_{2} \mathrm{Cl}_{2}$, rt, $2.5 \mathrm{~h}$

$5 \%$ DBU solution, dry $\mathrm{CH}_{2} \mathrm{Cl}_{2}, \mathrm{rt}, 2.0 \mathrm{~h}$

$5 \% \mathrm{DBU}$ solution, dry $\mathrm{CH}_{2} \mathrm{Cl}_{2}, \mathrm{rt}, 1 \mathrm{~h}$

$5 \%$ DBU solution, dry $1: 1$ toluene $/ \mathrm{CH}_{2} \mathrm{Cl}_{2}, \mathrm{rt}, 3 \mathrm{~h}$
Products (\% yield)

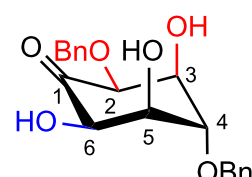

$5(60 \%)$
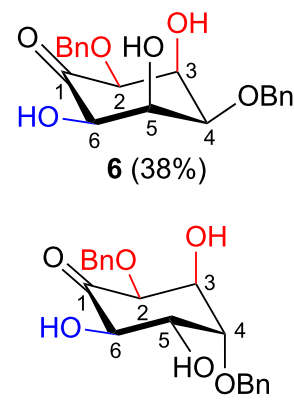

$7(64 \%)$
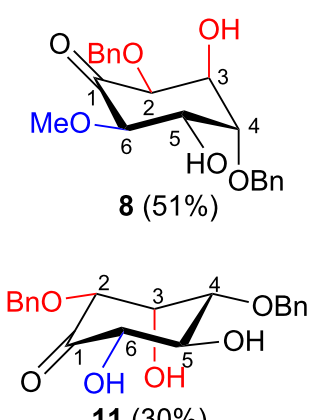

$11(30 \%)$

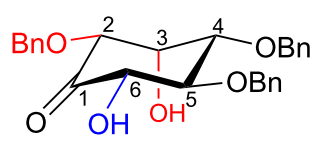

$12(30 \%)$

antramolecular cyclizations of 1 [33], 3 [34], and 4 [35] have been reported in previous works. 
In all the cases studied, only one of the four possible inososes was isolated. This was characterised by a cis axial-equatorial arrangement of the two oxygenated substituents on the new stereocentres ( 2 and 3 ) which were also cis to the other substituent $\alpha$ to the keto group (position 6). This 2,3,6-cis arrangement of the aldol products was observed irrespective to the stereochemistry of the other two positions (4 and 5), corresponding to the $\mathrm{C}-2$ and $\mathrm{C}-3$ of the parent dicarbonyl derivative.

To determine the effect of additional protecting groups on the reaction, the intramolecular aldol condensation was also performed on aldohexos-5-uloses of the L-lyxo and D-xylo series bearing a methyl protection on position 4 or a benzyl protection on position 3 (compounds 4 [35] and 10 [38], respectively). The stereo-outcome and the yields confirmed the cyclisation results obtained for dibenzyl derivatives.

Considering the results obtained, the intramolecular aldol condensation of the lyxo and arabino stereoseries affords the inososes in fairly good yields (54-60\%) [33-35], while the same reaction run on the ribo and xylo stereoseries gives the cyclization products only in moderate yields (30-38\%). In these latter cases, the colour of the reaction mixture changed over time from light yellow to dark orange. NMR analysis of the crude mixture verified the formation of a single inosose, which was the one isolated after chromatographic purification, together with indistinct side products possibly deriving by polycondensations or eliminations after the aldol condensation.

The structure and stereochemistry of inososes 5-8, 11, and 12 were confirmed by ${ }^{1} \mathrm{H},{ }^{13} \mathrm{C}$ and $2 \mathrm{D}$ NMR experiments. For example, the conformation of inosose $\mathbf{6}$ was established by the similar value of the vicinal proton coupling constants and by the presence of long-range coupling between $\mathrm{H}-2$ and $\mathrm{H}-6\left(J_{2,6}=\right.$ $1.4 \mathrm{~Hz})$, and $\mathrm{H}-3$ and $\mathrm{H}-5\left(J_{3,5}=2.6 \mathrm{~Hz}\right)$. For 11 and 12, the high value of the $J_{5,6}\left(9.4 \mathrm{~Hz}\right.$ and $8.5 \mathrm{~Hz}$, respectively) and $J_{4,5}$ (9.7 Hz and $9.3 \mathrm{~Hz}$ ), and the low value of the $J_{2,3}(2.4 \mathrm{~Hz}$ and $2.7 \mathrm{~Hz})$ and $J_{3,4}(2.2 \mathrm{~Hz}$ and $2.3 \mathrm{~Hz})$ agree with four substituents in the equatorial position for the preferred conformer.

A comparable example of intramolecular aldol condensation of a 1,5-dicarbonyl derivative has been reported by Tadano et al.
[39]. Almost a sole aldol product was obtained in a good yield and was characterised by the same 2,3,6-cis relationship observed in our experiments. In this case, the authors focused their attention only on the new formed chiral centres and on the cisorientation of their substituents. To rationalise the result obtained, they referred to the topological rules, which were proposed by Seebach and Golinski [40] to explain the preferred formation of the threo-configuration in intermolecular Michael additions. Unfortunately, not all these rules are applicable to the intramolecular reaction under investigation and, even more disappointing, they do not give any correlation between the two new chiral centres and the chiral centre $\alpha$ to the keto group which was already present on the parent dicarbonyl compound. Indeed, this appears as the most relevant and unexpected result of the present work. We performed the intramolecular aldol condensation on 4- and 6-deoxy-aldohexos-5-uloses of the L-arabino series (not shown). In the latter case, no reaction was observed even after longer reaction times. On the contrary, the C-4 deoxygenated compound afforded an inseparable complex mixture of products, possibly derived from a first carbocyclisation followed by elimination reactions.

In an attempt to find an explanation of the stereochemical outcome of the reaction, we directed our attention toward the open-transition-state models. These have been proposed to explain the prevalent formation of syn products, irrespective of the enolate geometry [41], in aldol reactions performed in the absence of a coordinating metal center (for instance, in the case of tin and zirconium enolates, and of "naked" enolates generated from enolsilanes [42]).

In the open-transition-state model, the enolate and the carbonyl group are orientated in an antiperiplanar fashion, maximazing the distance between the negatively charged oxygen atoms.

On these bases, a possible transition state for the intramolecular reaction, which considers also the 1,4,6-cis relationship (numbering referred to the dicarbonyl compound), is reported in Figure 2.

A working hypothesis is that the axial arrangement of electronwithdrawing substituents in positions 4 and 6 diminishes the

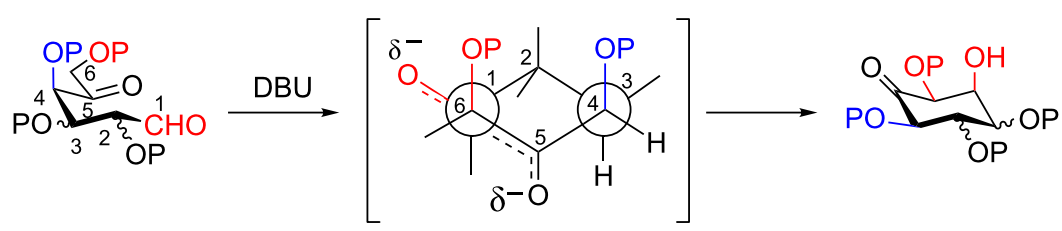


negative charge density on the 5-oxygen atom and decreases in this way the overall energy of the transition state, thereby favouring the intramolecular reaction. These kind of inductive effects in cyclic system has been reported before $[43,44]$.

The structure of every inosose obtained allows for complementary stereoselective reductions by choosing the proper reaction conditions. In fact (Table 1), the substituents $\alpha$ to the keto function (2 and 6) and the axial $\mathrm{OH}$ in position 3 have always a cis orientation which would favour an equatorially directed anti reduction using $\mathrm{NaBH}_{4}$ as a reducing reagent in an alcoholic solvent (condition $\mathbf{A}$ ). In particular, it has been proven that the axial $\mathrm{OH}$ group $\beta$ to the keto function plays a fundamental role in directing the nucleophilic attack [45-47]. It has also to be mentioned that by changing the experimental conditions (temperature and alcoholic solvent) a different diastereoselectivity has been reported in the reduction of the same protected inosose $[45,48]$. This highlights how subtle changes in the inosose structure and/or in the experimental conditions affect the stereooutcome of the reduction.

Also, the same free axial hydroxy function, deriving from the aldehyde which is beta to the carbonyl group (position 3), would allow for the complementary axial directed syn reduction using $\mathrm{NaBH}(\mathrm{OAc})_{3}$ in an $\mathrm{AcOH}-\mathrm{CH}_{3} \mathrm{CN}$ mixture through an intramolecular hydride transfer as reported by Evans [49] (condition $\mathrm{B}$ ). The axial $\mathrm{OH}$ function would be able to coordinate the reducing agent and thus give an internal hydride transfer from the same side through a six membered cyclic transition state (Figure 3)

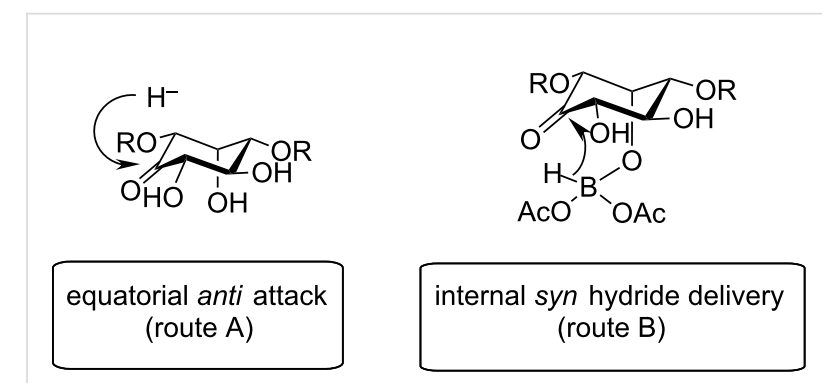

Figure 3: Stereoselective reduction of inosose intermediate.

In Table 2, the results of the complementary reductions (conditions A and B) are summarised (see Supporting Information File 1 for full experimental data). Seven different inositol derivatives 13-19 were obtained from the four inososes 5-7 and $\mathbf{1 1}$ in a stereoselective way, thereby controlling the stereochemistry of a third stereocentre of the inositol frame. The results of the reduction reactions are in good agreement with what has

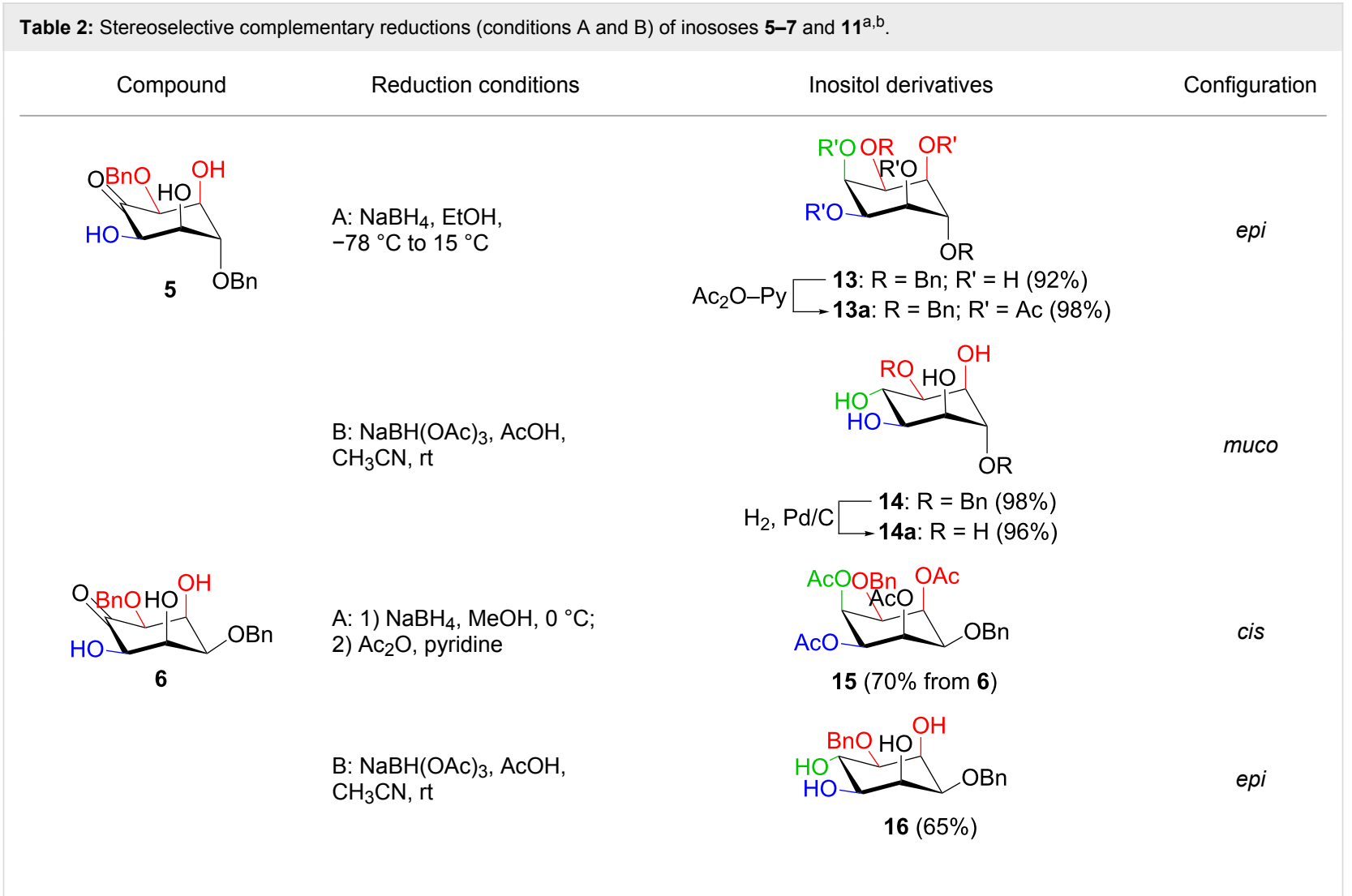


Table 2: Stereoselective complementary reductions (conditions $A$ and $B$ ) of inososes 5-7 and $11^{a, b}$. (continued)
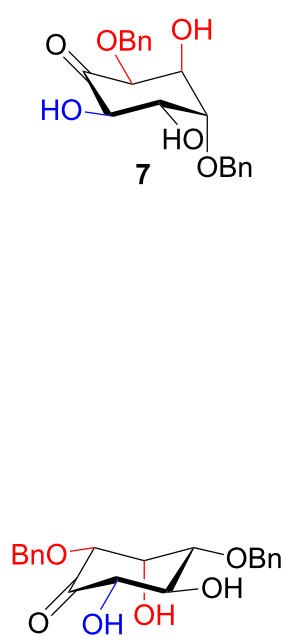

11
A: $\mathrm{NaBH}_{4}, \mathrm{EtOH}$, $-78^{\circ} \mathrm{C}$ to $15^{\circ} \mathrm{C}$

$\mathrm{B}: \mathrm{NaBH}(\mathrm{OAc})_{3}, \mathrm{AcOH}$, $\mathrm{CH}_{3} \mathrm{CN}$, rt

A: $\mathrm{NaBH}_{4}, \mathrm{MeOH}$, $0^{\circ} \mathrm{C}$

$\mathrm{B}: \mathrm{NaBH}(\mathrm{OAc})_{3}, \mathrm{AcOH}$, $\mathrm{CH}_{3} \mathrm{CN}$, rt

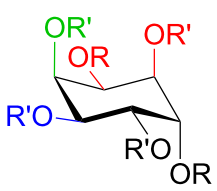

allo

1) $\mathrm{H}_{2}, \mathrm{Pd} / \mathrm{C}-17: \mathrm{R}=\mathrm{Bn} ; \mathrm{R}^{\prime}=\mathrm{H}(91 \%)$

2) $\mathrm{Ac}_{2} \mathrm{O}-\mathrm{Py} \longrightarrow$ 17a: $\mathrm{R}=\mathrm{R}^{\prime}=\mathrm{Ac}(87 \%$ from 7$)$

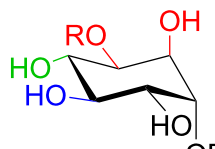

OR

$\mathrm{H}_{2}, \mathrm{Pd} / \mathrm{C}$

18: $R=B n(45 \%)$

$\rightarrow 18 \mathrm{a}: \mathrm{R}=\mathrm{H}(77 \%)$

OR OR OR

$\mathrm{Ac}_{2} \mathrm{O}-\mathrm{Py} \longrightarrow$ 16: $\mathrm{R}=\mathrm{H}(87 \%)$
$\longrightarrow$ 16a: $\mathrm{R}=\mathrm{Ac}(95 \%)$

epi

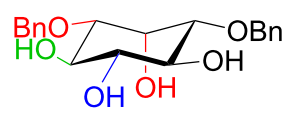

$19(70 \%)$

a Inositol derivatives in the table are represented in the way they are obtained as a result of the stereoselective reduction and the preferred conforma-

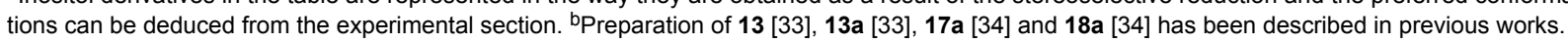

been reported before on similar compounds [45]. The structure and stereochemistry of inositols $\mathbf{1 3 - 1 9}$ were confirmed by ${ }^{1} \mathrm{H}$, ${ }^{13} \mathrm{C}$ and $2 \mathrm{D}$ NMR experiments directly or after per-acetylation of the reduction product and/or through comparison with previously reported compounds.

Noteworthy, the two step sequence performed on the D-xylo derivative 11 leads to myo-inositol derivative 19 when $\mathrm{NaBH}(\mathrm{OAc})_{3}$ is employed in the stereoselective reduction of the inosose and represents the biomimetic conversion of D-xyloaldohexos-5-ulose derivatives into myo-inositol derivatives.

As well as the stereoselective synthesis of enantiopure inositol derivatives, also the possibility to pick and tag specific positions of the inositol ring, installing the protective groups earlier on the carbohydrate frame through the well-known sugar chemistry, is of extreme interest. Although some attractive findings have been reported so far $[46,47]$, the regioselective protection of inositols is still a troublesome area due to the comparable reactivity of the secondary hydroxy functions. Therefore, the carbocyclization of a selectively protected dicarbonyl sugar, namely the L-lyxo derivative $\mathbf{2 0}$, whose synthesis will be presented in a forthcoming paper, has been investigated (Scheme 2).

The expected inosose 21 was obtained under standard conditions and was then submitted to the reduction step with $\mathrm{NaBH}(\mathrm{OAc})_{3}$. The D-chiro derivative 22 was isolated in a $47 \%$ yield over two steps and with complete stereoselectivity in accordance with the predicted stereo-outcome.<smiles></smiles>

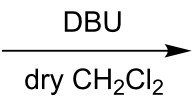

dry $\mathrm{CH}_{2} \mathrm{Cl}_{2}$

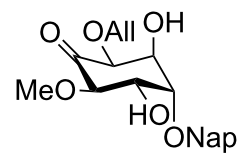

$21(65 \%)$
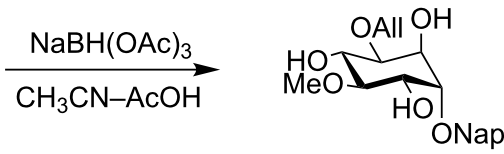

$22(72 \%)$ 
In this way, the orthogonal protecting groups (allyl and naphthalenylmethyl) installed on aldohexos-5-ulose 20, differentiated the two 1,2-cis hydroxy couples (2,3 and 4,5 positions) of 22 which can be easily transformed further in a selective manner.

\section{Conclusion}

The intramolecular aldol condensation of aldohexos-5-ulose derivatives of the four stereoseries has been studied. By obtaining the inosose derivatives shown, a better understanding of the relative influence of each position on the stereochemical course of the reaction was gained. These findings allowed us to formulate a plausible rationalization of the mechanism based on opentransition-state models and on inductive effects of axial anti arranged electron-withdrawing substituents.

The overall process, condensation followed by reduction, which involves the formation of three new stereocentres, represents a general access to inositol derivatives. In particular, in a complete stereoselective fashion, inositols of six different configurations characterised by the 2,3,6-cis arrangement of three substituents were obtained from aldohexos-5-uloses. Furthermore, the formal synthesis of L-chiro-inositol could be considered as achieved starting from known D-lyxo-aldohexos-5-ulose derivatives [37,50]. Even if in some cases yields of isolated compounds are not too high, this sugar-based approach gives access directly to enantiomerically pure inositol derivatives. This avoids time and cost-consuming desymmetrisation procedures required when myo-inositol is used as starting material in the preparation of inositol derivatives.

In addition, introducing a suitable pattern of protecting groups in the sugar frame, which will then be present in the inositol ring, has been shown. This allows for an indirect regioselective differentiation of the inositols' secondary hydroxy groups, which is difficult to achieve by common chemical means.

\section{Supporting Information}

\section{Supporting Information File 1}

Experimental procedures, characterization data of new compounds and ${ }^{1} \mathrm{H}$ and ${ }^{13} \mathrm{C}$ NMR spectra of compounds 6 , 11, 12, 14-16, 16a, 18, 19 and 21, 22.

[http://www.beilstein-journals.org/bjoc/content/ supplementary/1860-5397-12-227-S1.pdf]

\section{Acknowledgements}

This study was supported by the Italian Ministry of Education, University and Research (MIUR) within the frame of the
COFIN national project anno 2010-2011 - prot. 2010 JMAZML_008.

\section{References}

1. Kılbaş, B.; Balci, M. Tetrahedron 2011, 67, 2355-2389. doi:10.1016/j.tet.2011.01.012

2. Duchek, J.; Adams, D. R.; Hudlicky, T. Chem. Rev. 2011, 111, 4223-4258. doi:10.1021/cr1004138

3. Irvine, R. F.; Schell, M. J. Nat. Rev. Mol. Cell Biol. 2001, 2, 327-338. doi:10.1038/35073015

4. Chi, T. H.; Crabtree, G. R. Science 2000, 287, 1937-1939. doi:10.1126/science.287.5460.1937

5. Odom, A. R.; Stahlberg, A.; Wente, S. R.; York, J. D. Science 2000, 287, 2026-2029. doi:10.1126/science.287.5460.2026

6. Chung, S.-K.; Shin, B.-G.; Chang, Y.-T.; Suh, B.-C.; Kim, K.-T. Bioorg. Med. Chem. Lett. 1998, 8, 659-662. doi:10.1016/S0960-894X(98)00081-X

7. Hank, T.; Stricker, R.; Krishna, U. M.; Falck, J. R.; Chang, Y. T.; Chung, S. K.; Reiser, G. Eur. J. Biochem. 1999, 261, 577-584. doi:10.1046/j.1432-1327.1999.00326.x

8. Tagliaferri, F.; Wang, S.-N.; Berlin, W. K.; Outten, R. A.; Shen, T. Y. Tetrahedron Lett. 1990, 31, 1105-1108. doi:10.1016/S0040-4039(00)88737-7

9. Guidot, J. P.; Le Gall, T. Tetrahedron Lett. 1993, 34, 4647-4650. doi:10.1016/S0040-4039(00)60646-9

10. Gigg, J.; Gigg, R. Carbohydr. Res. 1997, 299, 77-83. doi:10.1016/S0008-6215(96)00330-8

11. Riley, A. M.; Jenkins, D. J.; Potter, B. V. L. Carbohydr. Res. 1998, 314, 277-281. doi:10.1016/S0008-6215(98)00317-6

12. Husson, C.; Odier, L.; Vottéro, P. J. A. Carbohydr. Res. 1998, 307, 163-165. doi:10.1016/S0008-6215(98)00003-2

13. Gurale, B. P.; Sardessai, R. S.; Shashidhar, M. S. Carbohydr. Res. 2014, 399, 8-14. doi:10.1016/j.carres.2014.08.010

14. Kwon, Y.-U.; Lee, C.; Chung, S.-K. J. Org. Chem. 2002, 67, 3327-3338. doi:10.1021/jo016237a

15. Podeschwa, M.; Plettenburg, O.; vom Brocke, J.; Block, O.; Adelt, S.; Altenbach, H.-J. Eur. J. Org. Chem. 2003, 1958-1972. doi:10.1002/ejoc.200200572

16. Carless, H. A. J.; Busia, K. Tetrahedron Lett. 1990, 31, 1617-1620. doi:10.1016/0040-4039(90)80032-H

17. Motherwell, W. B.; Williams, A. S. Angew. Chem., Int. Ed. 1995, 34 , 2031-2033. doi:10.1002/anie.199520311

18. Mandel, M.; Hudlicky, T. J. Chem. Soc., Perkin Trans. 1 1993, 741-743. doi:10.1039/P19930000741

19. Hudlicky, T.; Mandel, M.; Rouden, J.; Lee, R. S.; Bachmann, B.; Dudding, T.; Yost, K. J.; Merola, J. S. J. Chem. Soc., Perkin Trans. 1 1994, 1553-1567. doi:10.1039/P19940001553

20. Desjardins, M.; Brammer, L. E., Jr.; Hudlicky, T. Carbohydr. Res. 1997, 304, 39-42. doi:10.1016/S0008-6215(97)00186-9

21. Brammer, L. E., Jr.; Hudlicky, T. Tetrahedron: Asymmetry 1998, 9 , 2011-2014. doi:10.1016/S0957-4166(98)00182-7

22. Ferrier, R. J.; Middleton, S. Chem. Rev. 1993, 93, 2779-2831. doi:10.1021/cr00024a008

23. Takahashi, H.; Kittaka, H.; Ikegami, S. Tetrahedron Lett. 1998, 39 , 9703-9706. doi:10.1016/S0040-4039(98)02231-X

24. Takahashi, H.; Kittaka, H.; Ikegami, S. J. Org. Chem. 2001, 66, 2705-2716. doi:10.1021/jo001575h

25. Das, S. K.; Mallet, J.-M.; Sinaÿ, P. Angew. Chem., Int. Ed. Engl. 1997, 36, 493-496. doi:10.1002/anie.199704931 
26. Jia, C.; Pearce, A. J.; Blériot, Y.; Zhang, Y.; Zhang, L.-H.; Sollogoub, M.; Sinaÿ, P. Tetrahedron: Asymmetry 2004, 15, 699-703. doi:10.1016/j.tetasy.2003.11.029

27. Sollogoub, M.; Mallet, J.-M.; Sinaÿ, P. Tetrahedron Lett. 1998, 39, 3471-3472. doi:10.1016/S0040-4039(98)00529-2

28. Chiara, J. L.; Martin-Lomas, M. Tetrahedron Lett. 1994, 35, 2969-2972. doi:10.1016/S0040-4039(00)76674-3

29. Guidot, J. P.; Le Gall, T.; Mioskowski, C. Tetrahedron Lett. 1994, 35, 6671-6672. doi:10.1016/S0040-4039(00)73464-2

30. Carpintero, M.; Fernández-Mayoralas, A.; Jaramillo, C. J. Org. Chem. 1997, 62, 1916-1917. doi:10.1021/jo9623898

31. Kiely, D. E.; Fletcher, H. G., Jr. J. Org. Chem. 1969, 34, 1386-1390. doi:10.1021/jo01257a042

32. Kiely, D. E.; Sherman, R. S. J. Am. Chem. Soc. 1975, 97, 6810-6814. doi:10.1021/ja00856a035

33. Pistarà, V.; Barili, P. L.; Catelani, G.; Corsaro, A.; D'Andrea, F.; Fisichella, S. Tetrahedron Lett. 2000, 41, 3253-3256. doi:10.1016/S0040-4039(00)00360-9

34. Catelani, G.; Corsaro, A.; D'Andrea, F.; Mariani, M.; Pistarà, V. Bioorg. Med. Chem. Lett. 2002, 12, 3313-3315. doi:10.1016/S0960-894X(02)00692-3

35. Catelani, G.; D'Andrea, F.; Griselli, A.; Guazzelli, L.; Legnani, L.; Toma, L. Tetrahedron Lett. 2008, 49, 4534-4536. doi:10.1016/j.tetlet.2008.05.040

36. Catelani, G.; Corsaro, A.; D'Andrea, F.; Mariani, M.; Pistarà, V.; Vittorino, E. Carbohydr. Res. 2003, 338, 2349-2358. doi:10.1016/j.carres.2003.08.001

37. Guazzelli, L.; Catelani, G.; D'Andrea, F. Carbohydr. Res. 2010, 345, 369-376. doi:10.1016/j.carres.2009.11.027

38. Catelani, G.; D'Andrea, F.; Guazzelli, L.; Pistarà, V. Carbohydr. Res. 2009, 344, 717-724. doi:10.1016/j.carres.2009.01.014

39. Tadano, K.; Kanazawa, S.; Takao, K.; Ogawa, S. Tetrahedron 1992, 48, 4283-4300. doi:10.1016/S0040-4020(01)80440-3

40. Seebach, D.; Goliński, J. Helv. Chim. Acta 1981, 64, 1413-1423. doi:10.1002/hlca.19810640518

41. Yamamoto, Y.; Yatagai, H.; Naruta, Y.; Maruyama, K. J. Am. Chem. Soc. 1980, 102, 7107-7109. doi:10.1021/ja00543a040

42. Murata, S.; Suzuki, M.; Noyori, R. J. Am. Chem. Soc. 1980, 102, 3248-3249. doi:10.1021/ja00529a062

43. Jensen, H. H.; Lyngbye, L.; Jensen, A.; Bols, M. Chem. - Eur. J. 2002, 8, 1218-1226. doi:10.1002/1521-3765(20020301)8:5<1218::AID-CHEM1218>3.0.CO; 2-X

44. Jensen, H. H.; Bols, M. Acc. Chem. Res. 2006, 39, 259-265. doi:10.1021/ar050189p

45. Jagdhane, R. C.; Patil, M. T.; Krishnaswamy, S.; Shashidhar, M. S. Tetrahedron 2013, 69, 5144-5151. doi:10.1016/j.tet.2013.04.081

46. Jagdhane, R. C.; Shashidhar, M. S. Eur. J. Org. Chem. 2010, 2945-2953. doi:10.1002/ejoc.201000009

47. Sureshan, K. M.; Shashidhar, M. S.; Praveen, T.; Das, T. Chem. Rev. 2003, 103, 4477-4504. doi:10.1021/cr0200724

48. Collet, C.; Chrétien, F.; Chapleur, Y.; Lamandé-Langle, S. Beilstein J. Org. Chem. 2016, 12, 353-361. doi:10.3762/bjoc.12.39

49. Evans, D. A.; Chapman, K. T.; Carreira, E. M. J. Am. Chem. Soc. 1988, 110, 3560-3578. doi:10.1021/ja00219a035

50. Adinolfi, M.; Barone, G.; ladonisi, A.; Mangoni, L. Tetrahedron Lett. 1998, 39, 2021-2024. doi:10.1016/S0040-4039(98)00161-0

\section{License and Terms}

This is an Open Access article under the terms of the Creative Commons Attribution License

(http://creativecommons.org/licenses/by/4.0), which permits unrestricted use, distribution, and reproduction in any medium, provided the original work is properly cited.

The license is subject to the Beilstein Journal of Organic Chemistry terms and conditions:

(http://www.beilstein-journals.org/bjoc)

The definitive version of this article is the electronic one which can be found at:

doi:10.3762/bjoc. 12.227 